\title{
Nesting ecology and floral resource of Xylocopa augusti Lepeletier de Saint Fargeau (Hymenoptera, Apidae) in Argentina
}

\author{
Mariano Lucia* ${ }^{* \dagger}$, María C. Telleria", Pablo J. Ramello* and Alberto H. Abrahamovich ${ }^{* \dagger}$ \\ * División Entomología, Museo de La Plata, Universidad Nacional de La Plata, Edificio Anexo Museo, Unidades de Investigación FCNyM, 122 y 60, \\ 1900FWA La Plata, Argentina, ${ }^{\dagger}$ CONICET, Consejo Nacional de Investigaciones Científicas y Técnicas, La Plata, Argentina and ${ }^{\ddagger}$ Laboratorio de \\ Sistemática y Biología Evolutiva - Museo de La Plata, Universidad Nacional de La Plata, Paseo del Bosque s/n, 1900FWA, La Plata, Argentina
}

\begin{abstract}
A total of 33 nests of Xylocopa augusti was studied during two consecutive seasons.
2 Nesting behaviour and floral resources used by the large carpenter bee X. augusti Lepeletier de Saint Fargeau were studied during the brood production season in an urban area in Argentina.

3 Biological information about nesting aspects inside and outside the nest was considered, paying particular attention to year-long activity, foraging flights throughout the day for nectar and pollen collection, nectar dehydration, oviposition, and pollen preference.

4 In the study area, $X$. augusti shows an univoltine life cycle, with a peak of nesting between October and December, which coincides with the greatest blooming period of the surrounding flora.

5 From 36 analyzed larval provision samples, 18 pollen types were identified, most of them belonging to ornamental trees or shrubs. Pollen from EucalyptusMyrceugenia glaucescens (Cambess.) D. Legrand and Kausel (Myrtaceae), Solanum sp.-Cyphomandra betacea (Cav.) Sendtn. (Solanaceae) and Erythrina crista-galli L. (Fabaceae) was dominant.

6 The ability to obtain pollen from poricidal anthers such as those of Solanum indicate the potential of X. augusti to be an excellent managed pollinator and a good candidate for pollinating Solanaceae, such as Solanum lycopersicum 'tomato' and Solanum melongena 'eggplant', which are economically important crops in this region.
\end{abstract}

Keywords Argentina, floral resources, large carpenter bees, nesting behaviour.

\section{Introduction}

The need for insect pollination in modern agriculture is a vital yet expensive factor in crop production (Abrol, 2012). Apis mellifera L. (Hymenoptera: Apidae) is usually suggested as the most important managed pollinator in commercial agriculture worldwide (Free, 1993; Kearns et al., 1998). However, it has been long demonstrated that honeybees are not efficient pollinators for all crops (O'Toole, 1997; Garibaldi et al., 2013); for example, for those plants that require vibratile or buzz pollination (i.e. the extraction of pollen from poricidal anthers using vibrations of the flight muscles) (Buchmann, 1983), some species of wild bees are more effective. However, only a few species of bumblebees (Bombus spp.), leaf-cutting bees (Megachile spp.) and mason

Correspondence: Mariano Lucia. Tel.: +549221 4228451; e-mail: mlucia@fcnym.unlp.edu.ar bees (Osmia spp.) are managed as commercial pollinators and used in commercial agriculture (Thorp, 2003; Torchio, 2003; Velthuis \& van Doorn, 2006; Pitts-Singer \& Cane, 2011).

The introduction of non-native managed pollinators for crop pollination and honey production can impact on native bee species through competition for resources or direct interaction and the introduction of pests and diseases (Goulson, 2003; Plischuk et al., 2009; Schmid-Hempel et al., 2014; Alvarez et al., 2015). Among the wild bees that were tested in different crops and considered as potentially manageable pollinators are species of the genus Xylocopa (Hogendoorn etal., 2000; Freitas \& Oliveira Filho, 2001; Buchmann, 2004). Commonly known as large carpenter bees, species of the genus Xylocopa Latreille (Apidae: Xylocopini) comprise conspicuous, large, hairy bees represented by 31 subgenera worldwide, with approximately 470 species being described, most of them occurring in tropical and subtropical areas of the world (Lucia et al., 2015). Species of 
Xylocopa commonly nest in solid wood, including structural timbers, or in dead stalks of plants, although some of them nest in the ground. Their social behaviour varies across species, from solitary to semisocial or primitively eusocial nests where the oldest female (mother or sister) feeds both young females and males via trophallaxis (Lucia et al., 2015). Compared with other non-Apis bees, carpenter bees are potentially more versatile for agricultural pollination services because of their polylectic habits, the ability to buzz pollinate, long activity seasons, hibernation as an adult, foraging when temperatures reach acceptable levels and the acceptance of artificial substrates for nesting (Buchmann, 2004; Keasar, 2010). Around the world, some of these species are effective pollinators on diverse crops, including on passion fruit, sunflowers, squash, tomato and eggplant, and they are already being used for this purpose in different countries (Gerling et al., 1989; Sihag, 1993a; Mardan, 1995; Hogendoorn etal., 2000; Aguiar-Menezes et al., 2002; Sadeh et al., 2007).

One of the first steps to developing a management system that uses a bee pollinator is to understand its biology (i.e. life cycle, nesting behaviour and floral preferences). The nesting biology of several Xylocopa species has been studied in Brazil (Camillo etal., 1986; Bernardino \& Gaglianone, 2008; Marchi \& Melo, 2010), Thailand (Hongjamrassilp \& Warrit, 2014), India (Sihag, 1993b, 1993c; Raju \& Rao, 2006) and Israel (Gerling etal., 1983), although no such studies exist for Argentinian species.

In the present study, we observe and describe the nesting behaviour and floral resources used by $X$. augusti in an urban area in northeastern Buenos Aires province, Argentina. The results obtained should provided useful information for use when evaluating this species as potential manageable pollinator and also promote the use of wild bees for crop pollination, especially those crops of particular interest commonly cultivated by small-scale farmers in the studied area, such as Capsicum spp. 'peppers', Solanum lycopersicum 'tomatoe' and Solanum melongena 'eggplant'.

\section{Materials and methods}

\section{Study area}

Field work was conducted at the Unidad de Vivero Forestal Universidad Nacional de La Plata (345 $54^{\prime} 39^{\prime \prime} \mathrm{S}, 57^{\circ} 55^{\prime} 37^{\prime \prime} \mathrm{W}$, $18 \mathrm{~m}$ a.s.1.) located in La Plata city, Argentina. The area comprises a total of 4 ha with a variety of cultivated trees accompanied by weeds and adventitious species. The dominant trees belong to diverse families such as Platanaceae (Platanus occidentalis L.), Tiliaceae (Tilia sp.), Myrtaceae (Eucalyptus sp.), Bignoniaceae (Jacaranda mimosifolia D. Don) and Fabaceae (Tipuana tipu Nenth. Kuntze). Scarce shrubs can be found in the area, including species of Fabaceae [Caesalpinia gilliesi (Hook.) D. Dietr., Parkinsonia aculeata L., Sesbania punicea (Cav.) Benth. and Spartium junceum L.] and Solanaceae (Solanum granuloso-leprosum Dunal). Among the adventitious species are a variety of families, with the most abundant being Asteraceae [Carduus sp. Cichorium intybus L., Sonchus oleraceus (L.) L., Picris echioides L. and Taraxacum officinale (L.) Weber] and Fabaceae (Lotus glaber Mill., Melilotus sp., Trifolium sp. and Vicia sp.). The native vine Passiflora coerulea, 'passion fruit', commonly occur on chain link fence.
The climate of the area is temperate, with an average temperature of $22^{\circ} \mathrm{C}$ in the warmest month and $8^{\circ} \mathrm{C}$ in the coldest; there is no dry season and the average annual precipitation ranges from 800 to $1000 \mathrm{~mm}$ (Cicchino et al., 2003).

\section{Nest observations}

Xylocopa augusti is a native, parasocial bee widely distributed in several countries of southern South America and is recorded in several provinces in Argentina. It is more widespread in the east, ranging from Buenos Aires to Formosa province, at the northern edge of its range (Lucia etal., 2014). This species constructs nests in the dead wood of tree trunks or branches of a wide diversity of plant families. The nests are structurally branched, with an entrance hole leading to a system of tunnels (Lucia et al., 2014) that may be continuously occupied and expanded for several generations. The observations were conducted in active artificial nests found in trap-nests that had been previously deployed for the purpose of the present study. The trap-nests consisted of internodes of canes (Arundo donax, Poaceae) closed at one end (by the node) and open at the other, with the size of the entrance varying from 12.50 to $17.00 \mathrm{~mm}$, and they were placed horizontally on open shelves in the field. Observations were made between 07.00 and $17.00 \mathrm{~h}$ by one observer during two nesting periods (from October to April); nesting observations (nest activities) were made from October to early January; and information about activity, mortality and founded nests was recorded from October to April of each season. A total of $287 \mathrm{~h}$ (17.220 min) of observations was recorded in the field during the nesting seasons. The sequence and duration of the inside/outside activities of each nest were observed and recorded, including: (1) inside the nest: (i) digging of brood cells; (ii) nectar dehydration: $b_{1}$ : at nest entrance and $b_{2}$ : inside the nest; (iii) deposition of pollen; (iv) preparation of provision mass; (v) construction of cell partition; (vi) egg laying (oviposition); and (vii) inactivity; (2) outside the nest (foraging activities): (i) nectar collection and (ii) pollen collection. The nests were classified as 'founded nest', when the trap nest was occupied by a female for the first time; 'active nest', when the female occupies the nest and carry out the nesting activities; and 'dead nest', when the founder female dies for some reason and the nest becomes inactive. A flashlight was used to record observations inside the nest and, aiming to determine whether the foraging trip was for nectar or pollen collection, the presence of pollen in the scopa was considered as a pollen foraging flight and absence was considered as a nectar foraging flight. Records of temperature and precipitation in the study area were obtained from the 'Departamento de Sismología e Información Meteorológica FCAG-UNLP', La Plata, Buenos Aires, Argentina. Photographs of the nests were taken, externally, with a FZ18 digital camera (Panasonic, Japan) and, internally, with a portable microscope.

\section{Sampling and pollen analysis}

To evaluate the pollen resources used by the female of $X$. august $i$ for feed larvae, one-quarter of the mass provision (approximately $0.5 \mathrm{~g}$ ) was sampled for quantitative and qualitative analyses. The samples were obtained from brood cells in active nests 


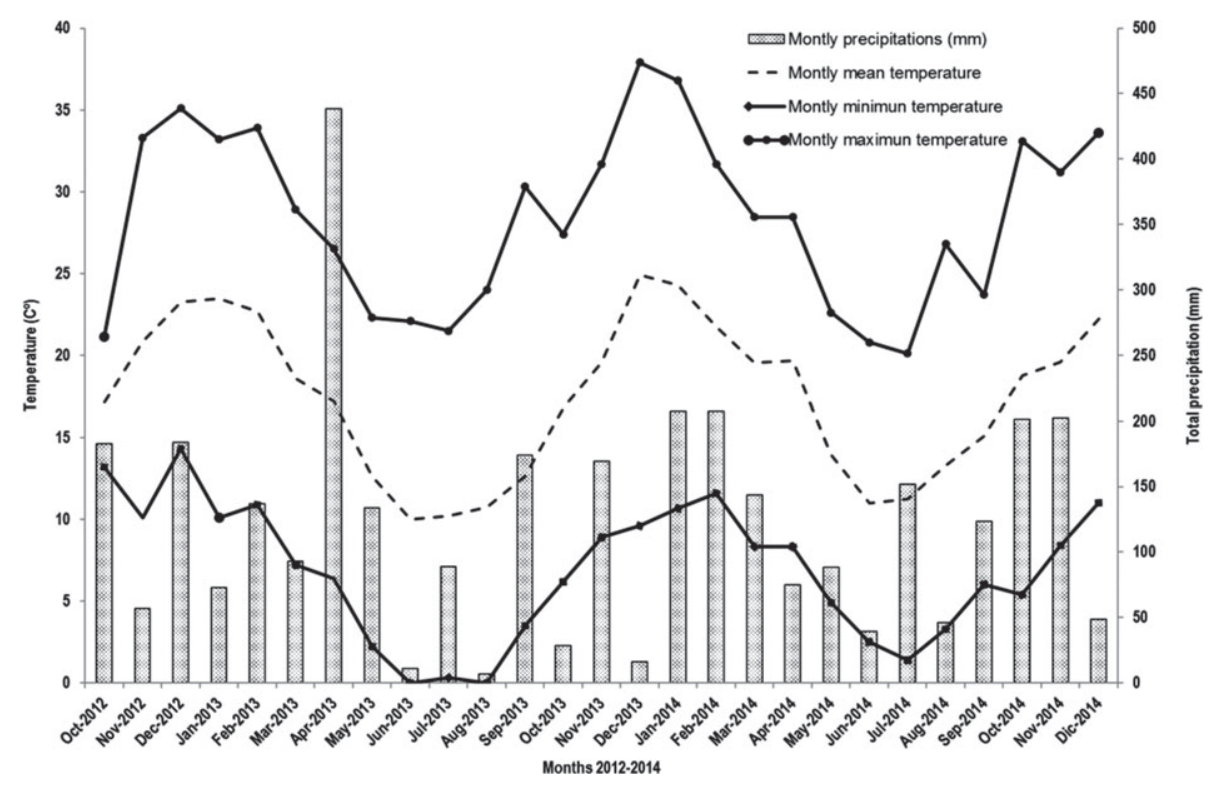

Figure 1 Climatic data obtained at the Departamento de Sismología e Información Meteorológica FCAG-UNLP, La Plata, Buenos Aires, Argentina. The monthly minimum, maximum and average temperatures for 2012-2014 are shown.

during the 2 years: 19 samples from October to December in 2012 and 17 samples from October to November in 2013. Each pollen sample was first dissolved by stirring it with a glass rod in $100 \mathrm{~mL}$ of distilled water at $80-90^{\circ} \mathrm{C}$, and then stirred for $10-15$ min with a magnetic stir. The mixture was filtered through a $250-\mu \mathrm{m}$ mesh to remove debris. From this aqueous mixture, $5 \mathrm{~mL}$ was centrifuged at $472 \mathrm{~g}$ for $10 \mathrm{~min}$. Subsequently, the pollen sediment obtained was acetolyzed in accordance with the procedure of Erdtman (1960). Slide preparations were made with acetolyzed pollen. Pollen samples of the flora surrounding the nesting area were considered to identify the pollen obtained from the mass provision. A sample of 300 grains on each slide was counted to establish the percentage of pollen types comprising the provision masses. Pollen counts were made at $\times 40$ magnification along regularly-spaced traverses of the slides until the pollen sum was reached.

\section{Results}

A total of 33 nests of $X$. augusti were studied during two consecutive seasons: 2012-2013 and 2013-2014.

\section{Seasonality}

The nesting activity of $X$. augusti females begins after an inactive overwintering period from mid-April until late September. This period is determined mainly by low temperatures (Fig. 1) and a scarce floral resource (pollen and nectar). Before nesting activities begin, females can be seen making flights that do not involve pollen collection; instead, they only make trips to collect nectar usually from Passiflora flowers (late September to early October). Pollen foraging by females to prepare the larval food usually begins in early or mid-October and lasts until
January. Females begin to enclose the first cells in mid-October, and the last cell enclosed was recorded in late January. New nest foundation occurred mostly between October and December, the percentage of nests founded during these months was similar in both studied periods, approximately $90 \%$ (31 nests) in 2012-2013 and $81.5 \%$ (27 nests) in 2013-2014 (Fig. 2). However, some nests were founded during in January and February, although only the nests founded in January had brood cells.

\section{Cell construction}

The female starts the nesting sequence by digging a new cell. The female scrapes the cane walls with her mandibles to give a barrel shape and discards the sawdust through the nest entrance (Fig. 3A-C). Periods of excavation were completed before starting the provision of a new brood cell. The time spent on cell excavation was variable, taking between 4 and $241 \mathrm{~min}$ (mean \pm SD: $45.73 \pm 54.16, n=30$ ). Excavation periods were almost always alternated with a short inactivity period or by flights for nectar collection just for adult intake.

\section{Foraging activities}

Pollen collection and cell provisioning. After finishing preparing the walls of the brood cell (Fig. 3C), females start accumulating pollen to prepare a larval provision. The female begins by making trips to collect pollen (Fig. 3D). The time spent in this process was variable and took from 2 to 36 min (mean \pm SD: $8.7 \pm 5.8$, $n=76$ trips, 15 females observed), with $46 \%$ of trips occurring within 5-10 min and $34 \%$ within $1-5 \mathrm{~min}$ (Fig. 4). In general, the number of trips made by a female each day varied from 1 to 13 (mean \pm SD: $4.36 \pm 3.8$ ) (Fig. 5). When returning from a foraging trip, the female went directly to the cell, directed the abdomen towards the end of it and rubbed the hind legs together 


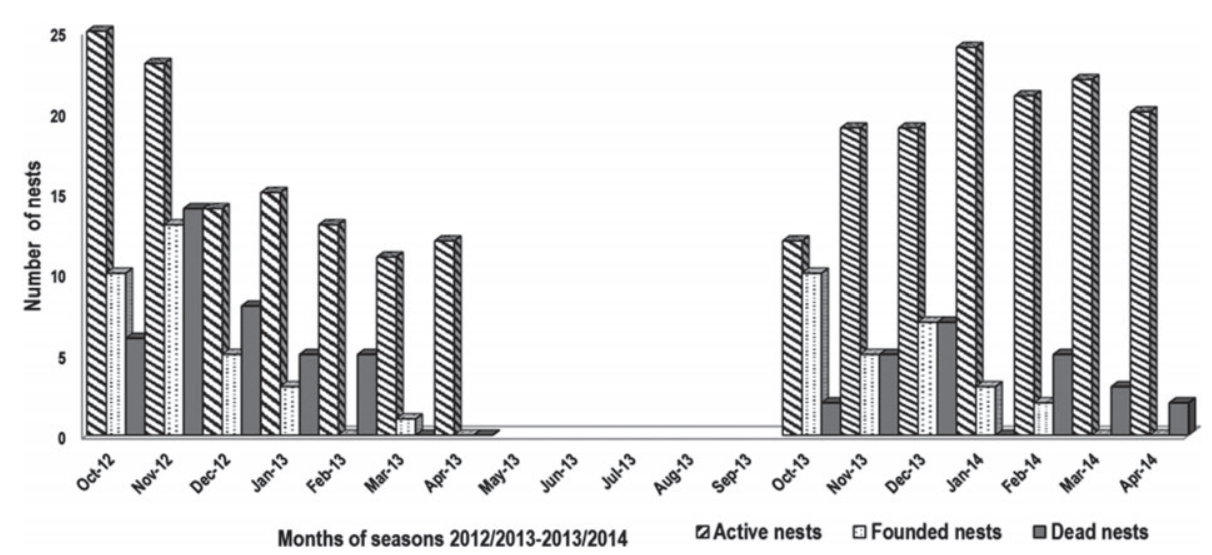

Figure 2 Number of active, founded and dead Xylocopa augusti nests per month from October 2012 to April 2014 in La Plata, Argentina.

to deposit the pollen accumulated on the scopa (Fig. 3E). The time spent in this process varied, lasting $1-13$ min (mean \pm SD: $4.7 \pm 2.5, n=106)$. Pollen foraging occurred mainly in the morning $(07.00-12.00 \mathrm{~h})$, comprising $71.2 \%$ of all trips observed, with the remaining trips $(28.8 \%)$ occurring in the afternoon $(12.00-17.00 \mathrm{~h})$ (Fig. 6). The pollen is accumulated in the brood cell, increasing with each trip. After the pollen is deposited, the bee often spent a short time motionless inside the nest, possibly resting before leaving for more pollen.

Nectar collection. Once the pollen provision is sufficiently large, the female begins to collect nectar for moistening the pollen to finish preparing the provision mass (Fig. $3 \mathrm{~F}$ ). These trips may take from 1 to 63 min (mean \pm SD: $9.37 \pm 10.3, n=177$ ), with $40.7 \%$ of trips occurring within $1-5 \mathrm{~min}$ and $37.85 \%$ within 5-10 min (Fig. 4). One female (nest 49) made a maximum of 31 trips for nectar collection in a day that lasted between 1 and 26 min (mean \pm SD: $5 \pm 4.4$ ). The trips per female per day varied from 2 to 31 (mean \pm SD: $6.09 \pm 6.34$ ) (Fig. 5). Although trips for nectar usually occurred after the cell was provisioned with pollen, there were other times when the female left to collect nectar: during the brood cell excavation, during construction of the partition or after a period of inactivity. The $69.2 \%$ of nectar foraging trips occurred mainly in the afternoon $(12.00-17.00 \mathrm{~h})$, whereas others occurred in the morning (07.00-12.00 h) (Fig. 6). To moisten the accumulated pollen, females dehydrate nectar (evaporation of water from nectar) before mixing it with pollen to form a pollen loaf as the larval provisions (Wittmann \& Scholz, 1989) (Fig. 3G-H). These behaviours related to nectar dehydration occurred inside the nest or at the nest entrance. The time spent in this process was variable and lasted 3-70 min (mean \pm SD: $10.97 \pm 11.82, n=37$ ) at the nest entrance and $2-66$ min (mean \pm SD: $13.58 \pm 11.95, n=90)$ inside the nest. The $70.9 \%$ of the cases occur inside the nest and the $29.1 \%$ at the nest entrance (Fig. 7). The female added regurgitated droplets of nectar on the dry pollen after dehydration, after each trip of nectar collection (Fig. 3I-L). Because it occurred after pollen deposition, the bee often spent some time motionless inside the nest before leaving to visit more flowers. Males also dehydrated nectar within 4-45 min (mean \pm SD: $21.1 \pm 12.40, n=10$ ) at the nest entrance, before leaving for more flights.
Oviposition. Regarding the oviposition process, first, the female mixes the pollen with her head, mouthparts and forelegs, creating a mass provision onto which the egg will be laid (Fig. 8A). Then, the female pushes the pollen mass backwards through her legs (Fig. 8B,C) in a process that can take from 8 to 20 min depending on the provision size (mean $\pm \mathrm{SD}: 13.3 \pm 3.86, n=10)$. Once this process is finished, the bee turns around and stands facing the mass to position it under her (Fig. 8D). This may last between 4 and $8 \mathrm{~min}$ (mean $\pm \mathrm{SD}: 5.30 \pm 1.34, n=10)$. The last step before laying the egg includes moving the mass to the final position by lifting it repeatedly with the legs and pressing it with the metasoma to give the final shape (Fig. 8E,F). Finally, the female begins to make systematic movements with her antennae (slow up and down movements) and mid-front legs, then lifts up the metasoma and lays the egg when moving forward (Fig. 8G). This process may take from 2 to 4 min (mean \pm SD: $2.50 \pm 0.71$, $n=10)$. The eggs were laid mostly in the afternoon $(n=8,10$ observations in total) and, immediately after this, the female starts building the cell partition.

Building the cell partitions. To construct the cell partition, the female scrapes the cane walls to remove sawdust that is moistened with saliva. Immediately, the sawdust is moved toward the hind legs and pasted on the sides of the tunnel walls with the aid of the metasoma (Fig. 8H). During partition construction, females spent most of the time with their heads looking straight towards the nest entrance. The time spent building the cell partition was variable, lasting between 112 and 182 min (mean \pm SD: $139 \pm 26.76, n=6$ ). In some cases, prior to concluding the partition, the female came out of nest several times when it was still incomplete (Fig. 8I) to collect nectar. These trips lasting between 5 and $11 \mathrm{~min}(n=3)$. The total time spent for cell construction, including the provisioning, oviposition and construction of the cell partition, was between 1 and 5 days (mean \pm SD: $3.15 \pm 1.28, n=13$ ).

Pollen robbery. Pollen robbery was only carried out by conspecific females and pollen was only robbed from cells still under construction. The time spent on pollen robbery varied, lasting from 15 to $27 \mathrm{~s}$ (mean \pm SD: $21 \pm 4.65, n=7$ ). A female might inspect several potential nests before robbing it. 


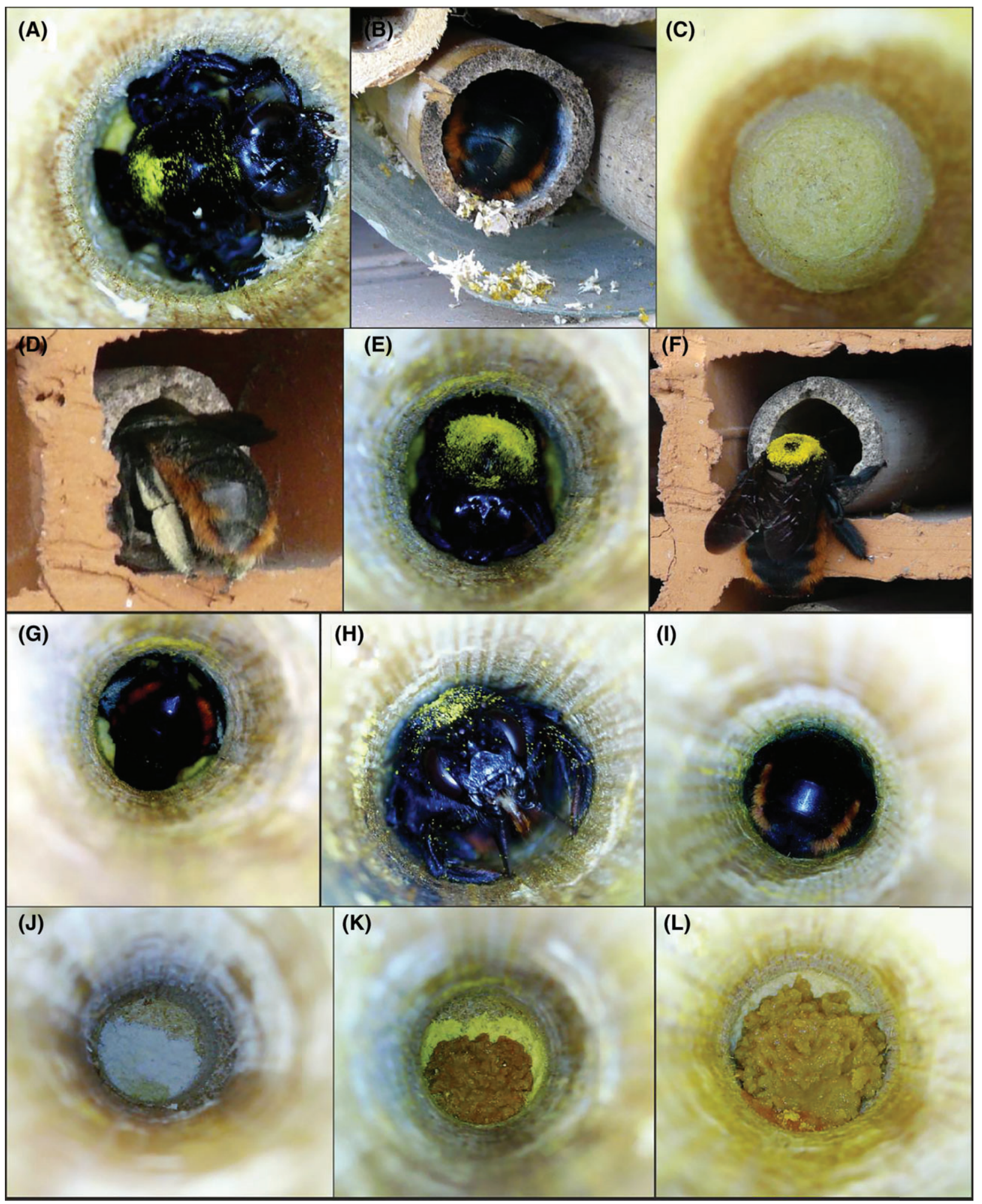

Figure 3 Sequence of cell construction and provisioning by Xylocopa augusti females: (A) digging a new cell by scraping the cane walls with her mandibles; (B) removing excess sawdust; (C) cell excavation complete; (D) female arriving with pollen in the scopa; (E) deposition of pollen in the cell; (F) arriving from a nectar-collecting trip; $(G)$ to $(H)$ female dehydrating nectar inside of nest; (I) female mixing the dry pollen with nectar; (J) dry pollen with a portion wetted with nectar; (K) pollen, dry and wet; and (L) pollen completely mixed with nectar. [Colour figure can be viewed at wileyonlinelibrary.com] 


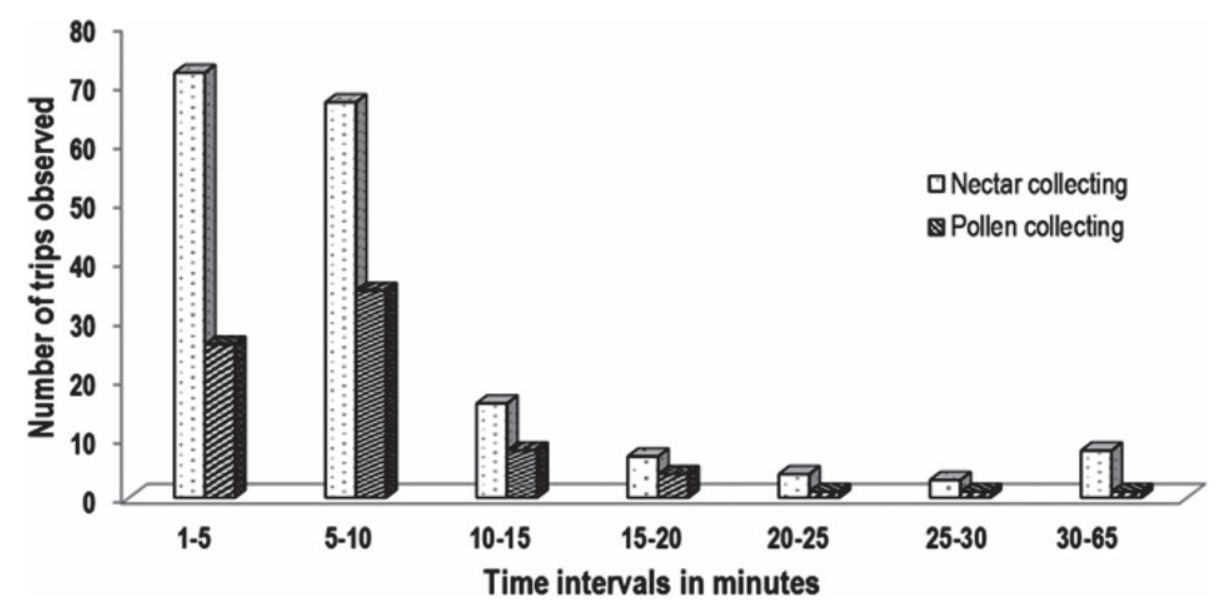

Figure 4 Trip durations per nest made by 15 Xylocopa augusti females discriminated in time intervals.

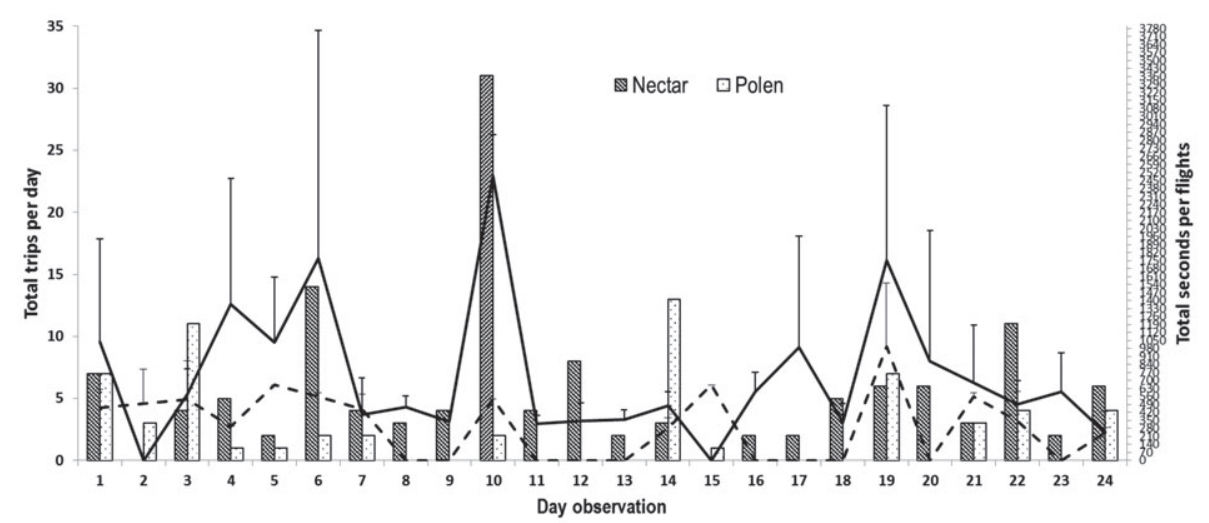

Figure 5 Trips made by 18 Xylocopa augusti females observed per nest during 24 days of observations. A dashed line indicates the pollen collecting trips and solid line nectar collecting. Trip average expressed in seconds.

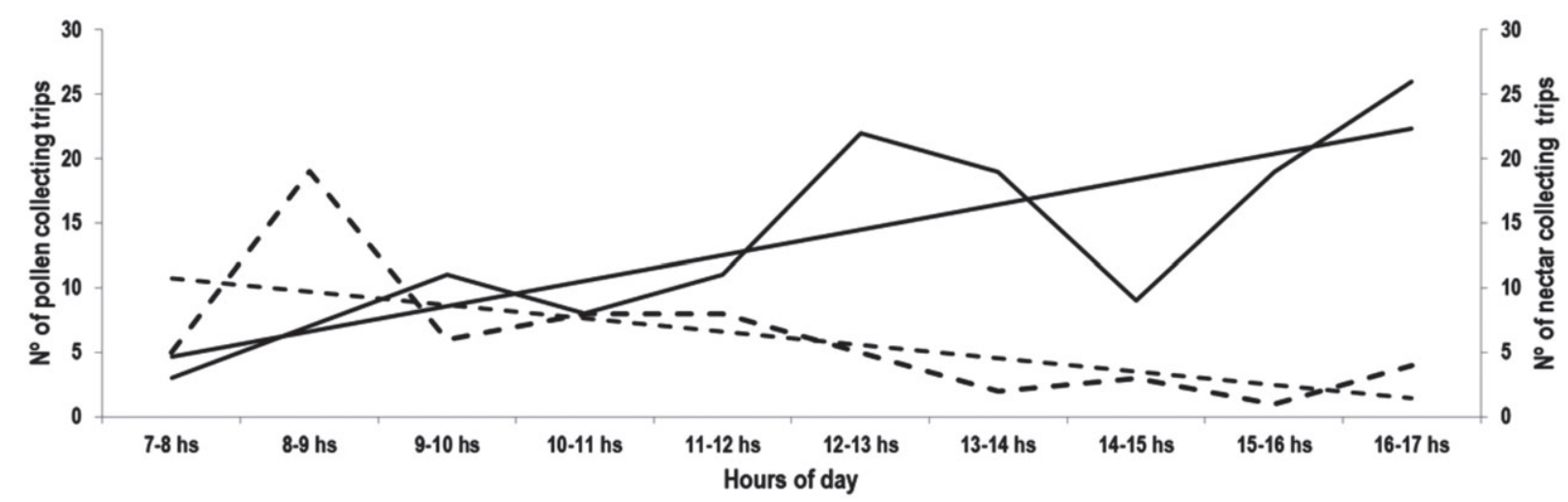

Figure 6 Collecting activity (pollen and nectar) of Xylocopa augusti females related to the time of day. A dashed sinuous line represents the pollen collecting trips and a solid sinuous line indicates nectar collecting. A straight, dashed and solid line represents the tendency of trips throughout the day. 


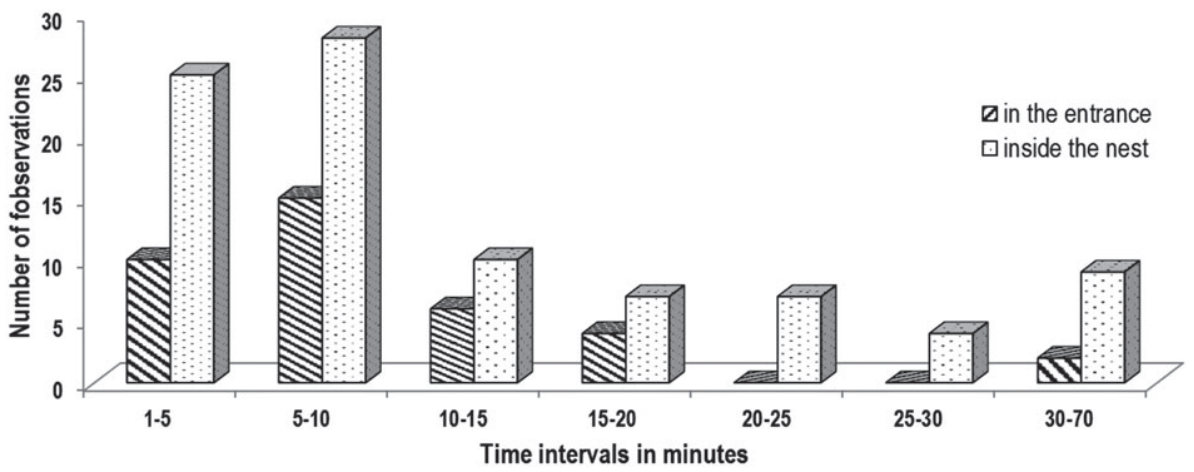

Figure 7 Observations of nectar dehydration by 13 Xylocopa augusti females occurring inside the nest and at the entrance; discriminated into time intervals.

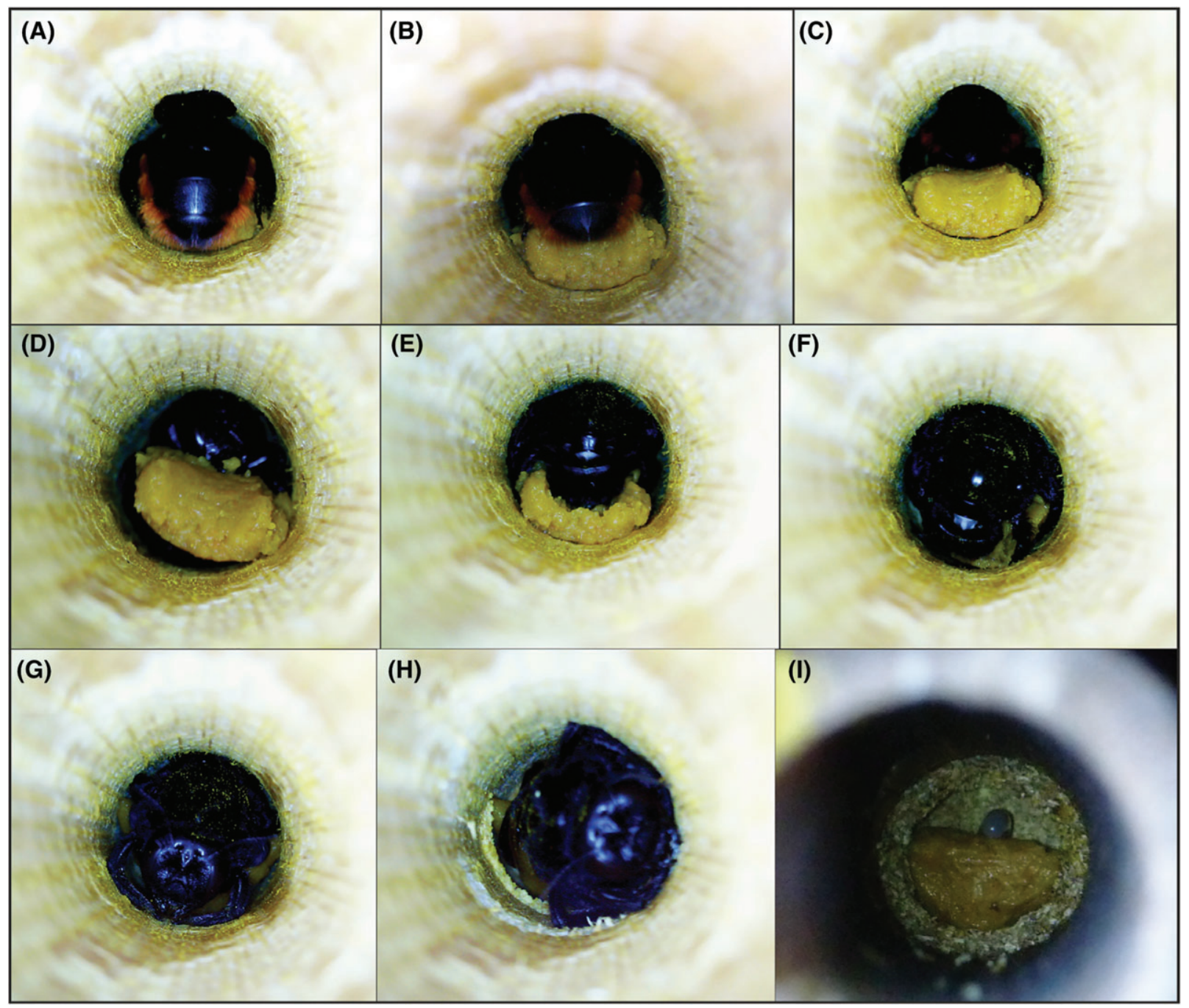

Figure 8 Sequence of oviposition of female of Xylocopa augusti. (A) female mixing the pollen with her head and mouthparts several times with glandular secretions, creating a mass provision to lay the egg on it; $(B-C)$ female pushes the mass provision backwards through her legs; (D-F) pollen accumulated in front then moving the mass to the final position by lifting it repeatedly with the legs and pressing it with the metasoma to give the final shape to the bee bread; $(G)$ oviposition position; $(H)$ female begins construction of the cell partition; and (I) mass provision with egg situated on top. [Colour figure can be viewed at wileyonlinelibrary.com]. 
Table 1 Relative frequency of pollen source taxa present in samples of provisions masses of Xylocopa augusti collected during 2012 and 2013

\begin{tabular}{|c|c|c|c|c|c|c|c|c|c|c|c|c|c|c|c|c|c|c|}
\hline \multirow[b]{2}{*}{ Taxa } & \multicolumn{18}{|c|}{ Relative frequency of pollen types (\%) } \\
\hline & $\mathrm{O} / 12$ & $0 / 12$ & $\mathrm{O} / 12$ & $\mathrm{O} / 12$ & $\mathrm{O} / 12$ & $0 / 12 \wedge$ & $N / 12 \quad N / 12$ & $\mathrm{~N} / 12$ & $\mathrm{D} / 12$ & $\mathrm{D} / 12$ & $\mathrm{D} / 12$ & $0 / 13$ & $0 / 13$ & $0 / 13$ & $0 / 13$ & $\begin{array}{lll}3 & 01 / 3\end{array}$ & $0 / 13$ & $0 / 13$ \\
\hline \multicolumn{19}{|l|}{ Amaryllidaceae } \\
\hline \multicolumn{19}{|l|}{ Amaryllis sp. ^ } \\
\hline \multicolumn{19}{|l|}{ Asteraceae } \\
\hline Cichorium intybus $\wedge$ & & & & & & & 2 & & & & & & & & & & & \\
\hline \multicolumn{19}{|l|}{ Bignoniaceae } \\
\hline \multicolumn{19}{|l|}{ Catalpa bignonioides * } \\
\hline Tabebuia sp. * & & & & & & & & & & & & & & 3 & & & $\mathrm{P}$ & \\
\hline Brassicaceae $^{\wedge}$ & & & & & & & & & & & & 10 & & & & & & \\
\hline \multicolumn{19}{|l|}{ Casuarinaceae } \\
\hline Casuarina cuninghamiana * & & & & & & 1 & & & & & & & & & & & & \\
\hline \multicolumn{19}{|l|}{ Fabaceae } \\
\hline Erytrina crista-galli * & & & & & & & 31 & & 3 & 38 & 9 & & & & & & & \\
\hline \multicolumn{19}{|l|}{ Lotus sp. } \\
\hline Melilotus sp. ^ & & & & & & & & & & & & & & & & & & \\
\hline Parkinsonia aculeata+ & & & & 78 & & 13 & & 96 & & & $P$ & & & & & & $P$ & $P$ \\
\hline Sesbania punicea + & & & & & & & & & 4 & & & & & & & & & \\
\hline $\begin{array}{l}\text { Spartium junceum + } \\
\text { Trifolium repens ^ }\end{array}$ & 29 & & 15 & 22 & 23 & 12 & 3 & 3 & & 3 & $P$ & 4 & 7 & & & & & \\
\hline Vicia sp. $\wedge$ & & & & & & & $P$ & & & & & 1 & & $P$ & & & & \\
\hline Magnoliaceae & & & & & & & & & & & & & & & & & & \\
\hline Liriodendron tulipifera* & & & & & & & & & & & & 19 & 4 & 1 & & & & \\
\hline Meliaceae & & & & & & & & & & & & & & & & & & \\
\hline Melia azedarach * & 3 & $\mathrm{P}$ & $\mathrm{P}$ & & $\mathrm{P}$ & & & $\mathrm{P}$ & & & & & 4 & & $P$ & & & $\mathrm{P}$ \\
\hline Myrtaceae & & & & & & & & & & & & & & & & & & \\
\hline $\begin{array}{l}\text { Eucalyptus* sp. - Myrceugenia } \\
\text { glaucescens* }\end{array}$ & & 1 & & & & & 34 & & 3 & 1 & 7 & 55 & 84 & 96 & 100 & 100 & 100 & 100 \\
\hline Passifloraceae & & & & & & & & & & & & & & & & & & \\
\hline Passiflora caerulea ^ & 1 & 1 & $\mathrm{P}$ & $P$ & $P$ & 20 & 1 & $P$ & $P$ & 6 & & 2 & 1 & $\mathrm{P}$ & $P$ & $P$ & $\mathrm{P}$ & $\mathrm{P}$ \\
\hline Solanaceae & & & & & & & & & & & & & & & & & & \\
\hline $\begin{array}{l}\text { Solanum }{ }^{\star} \text { Cyphomandra }+ \\
\text { Unknow }\end{array}$ & 67 & 98 & 85 & & $\begin{array}{l}76 \\
1\end{array}$ & 54 & 96 & & $\begin{array}{l}88 \\
2\end{array}$ & 52 & $\begin{array}{l}84 \\
P\end{array}$ & 9 & & & & & & \\
\hline & Relative & frequen & ncy of pc & ollen typ & pes (\%) & & & & & & & & & & & & & \\
\hline Taxa & $\mathrm{O} / 13$ & $\mathrm{O} / 13$ & $\mathrm{O} / 13$ & $0 / 13$ & $\mathrm{O} / 13$ & $3 \quad N / 13$ & $3 \quad N / 13$ & $N / 13$ & $N / 13$ & $\mathrm{~N} / 13$ & $N / 13$ & $\mathrm{~N} / 13$ & $3 \quad N / 13$ & & V/13 & $N / 13$ & $N / 13$ & $\mathrm{~N} / 13$ \\
\hline Amaryllidaceae & & & & & & & & & & & & & & & & & & \\
\hline Amaryllis sp. ^ & & & & & & & & 1 & & & & & & $\mathrm{P}$ & b & & & 4 \\
\hline Asteraceae & & & & & & & & & & & & & & & & & & \\
\hline Cichorium intybus $\wedge$ & & & & & & & $P$ & & & & & & & & & & & \\
\hline Bignoniaceae & & & & & & & & 1 & & & & & & & & & & \\
\hline Catalpa bignonioides * & & & & & & & & & & & & & $P$ & & & & & \\
\hline Tabebuia sp. * & & & & & & & & & & & 2 & & & & & 2 & & \\
\hline Brassicaceae & & & & & & & & & & & & & & & & & & \\
\hline Fabaceae & & & & & & & & & & & & & & & & & & \\
\hline Erytrina crista-galli * & & & $\mathrm{P}$ & & & 1 & & 19 & & $\mathrm{P}$ & & & 24 & & & $\mathrm{P}$ & 40 & \\
\hline Lotus sp. $\wedge$ & & & & & & 15 & & & & & & & & & & & & \\
\hline Melilotus sp. ^ & & & & & & & & & & & & & 2 & & & & & \\
\hline $\begin{array}{l}\text { Parkinsonia aculeata + } \\
\text { Sesbania punicea + }\end{array}$ & $P$ & 18 & 13 & & & & & $P$ & & & 7 & & & & & & & \\
\hline Spartium junceum + & & & & 2 & & & & & & 4 & & & & & & & & 7 \\
\hline Trifolium repens $\wedge$ & & & & & & & & & & & & & $P$ & & & & & \\
\hline Vicia sp. $\wedge$ & & & & $P$ & & & & & & 2 & & $P$ & & & & & & \\
\hline Magnoliaceae & & & & & & & & & & & & & & & & & & \\
\hline Liriodendron tulipifera * & & 24 & & 5 & & & & & & & & & & & & & & \\
\hline Meliaceae & & & & & & & & & & & & & & & & & & \\
\hline Melia azedarach * & $P$ & & & & & $P$ & 3 & & & & 2 & $P$ & 2 & & & & & \\
\hline Myrtaceae & & & & & & & & & & & & & & & & & & \\
\hline $\begin{array}{l}\text { Eucalyptus *sp. - Myrceugenia } \\
\text { glaucescens + }\end{array}$ & 100 & 57 & 87 & 93 & 100 & 84 & 86 & 11 & 98 & 87 & 89 & 100 & 31 & & 100 & 98 & 56 & 24 \\
\hline Passifloraceae & & & & & & & & & & & & & & & & & & \\
\hline Passiflora caerulea ^ & $P$ & 1 & $\mathrm{P}$ & & P & $P$ & $P$ & 68 & 1 & $\mathrm{P}$ & $P$ & & $P$ & P & 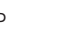 & $P$ & & 2 \\
\hline Solanaceae & & & & & & & & & & & & & & & & & & \\
\hline Solanum * Cyphomandra + & & & & & & & & & 1 & 7 & $P$ & & 39 & & & & 4 & 63 \\
\hline Unknow & & & & & & $P$ & 11 & & & & & & 4 & & & & & \\
\hline
\end{tabular}

Percentages derived from the pollen counts are rounded mathematically. ${ }^{\text {, herbs; }}{ }^{*}$, trees; + , shrubs. P, present; O, October; N, November; D, December. 


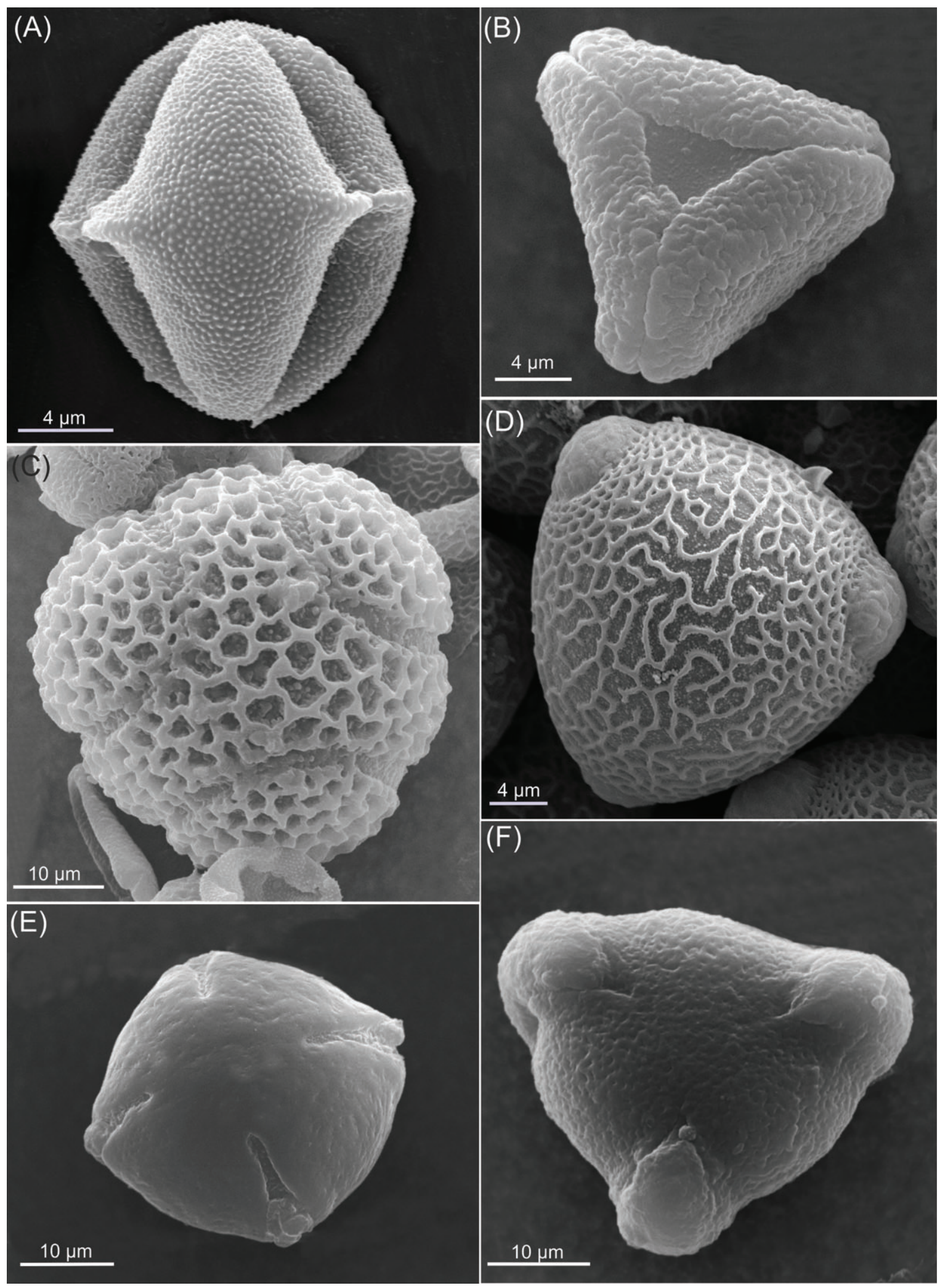

Figure 9 SEM micrographs of some pollen types collected by Xylocopa augusti: (A) Solanum sp., (B) Eucalyptus sp., (C) Passiflora caerulea, (D) Erythrina crista-galli, (E) Melia azedarach and (F) Spartium junceum. 


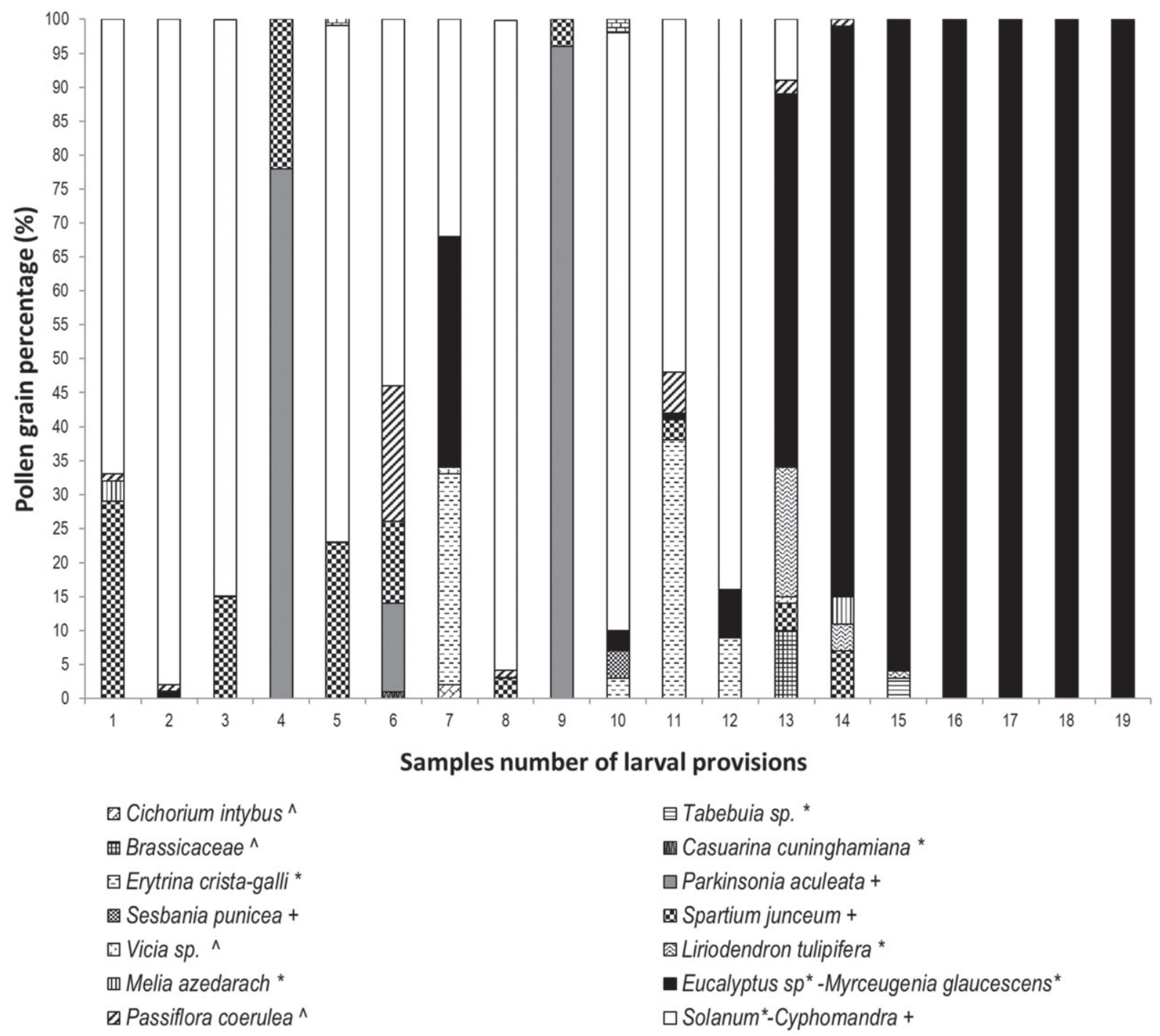

Figure 10 Percentages of most common pollen types present in samples of larval provisions of Xylocopa augusti collected during 2012. ^, herbs; * trees; +, shrubs.

\section{Pollen types encountered in nest}

From 36 analyzed provision masses, 18 pollen types belonging to 11 families were identified (Table 1). Pollen from Eucalyptus sp. and Myrceugenia glauscens, Solanum sp. and Cyphomandra betaceae was grouped as a result of morphological similarity. The number of pollen types found ranged from two to eight, most frequently being between three and six. Most of plants visited were ornamental trees or shrubs, followed by herbs. Usually, pollen from Eucalyptus sp.- Myrceugenia glaucescens, Solanum sp.- Cyphomandra betacea and two Fabaceae: Erythrina crista-galli and Spartium junceum L. were the best represented in the diet of the larvae (Fig. 9). Another plant intensely but sporadically collected was Parkinsonia aculeata L., followed by Liriodendron tulipifera L. Other pollen sources identified, although in very small amounts, included Amaryllis sp., Cichorium intybus, Catalpa bignonioides Walter, Fl. Carol. Tabebuia sp., Brassicaceae, Casuarina cunninghamiana Miq., Lotus sp.,
Melilotus sp., Sesbania punicea, Trifolium repens L., Vicia sp., Melia azedarach L. and Passiflora caerulea (Figs 10 and 11 and Table 1). Passiflora caerulea was present in most provision masses, although always at low percentages.

\section{Discussion}

In the present study, we describe the nesting behaviour of $X$. augusti during the nesting season. The pattern followed by $X$. august $i$ in building the nest was similar to that described by Michener (1964) for most nonsocial species of bees and also similar to that observed in other neotropical species of Xylocopa (Camillo \& Garófalo, 1982; Camillo et al., 1986; Marchi \& Melo, 2010; Pereira \& Garófalo, 2010). However, the present study provided new data about nesting behaviour, including floral preferences of X. augusti, as well as some details of collecting behaviour. Xylocopa augusti begins making trips to 


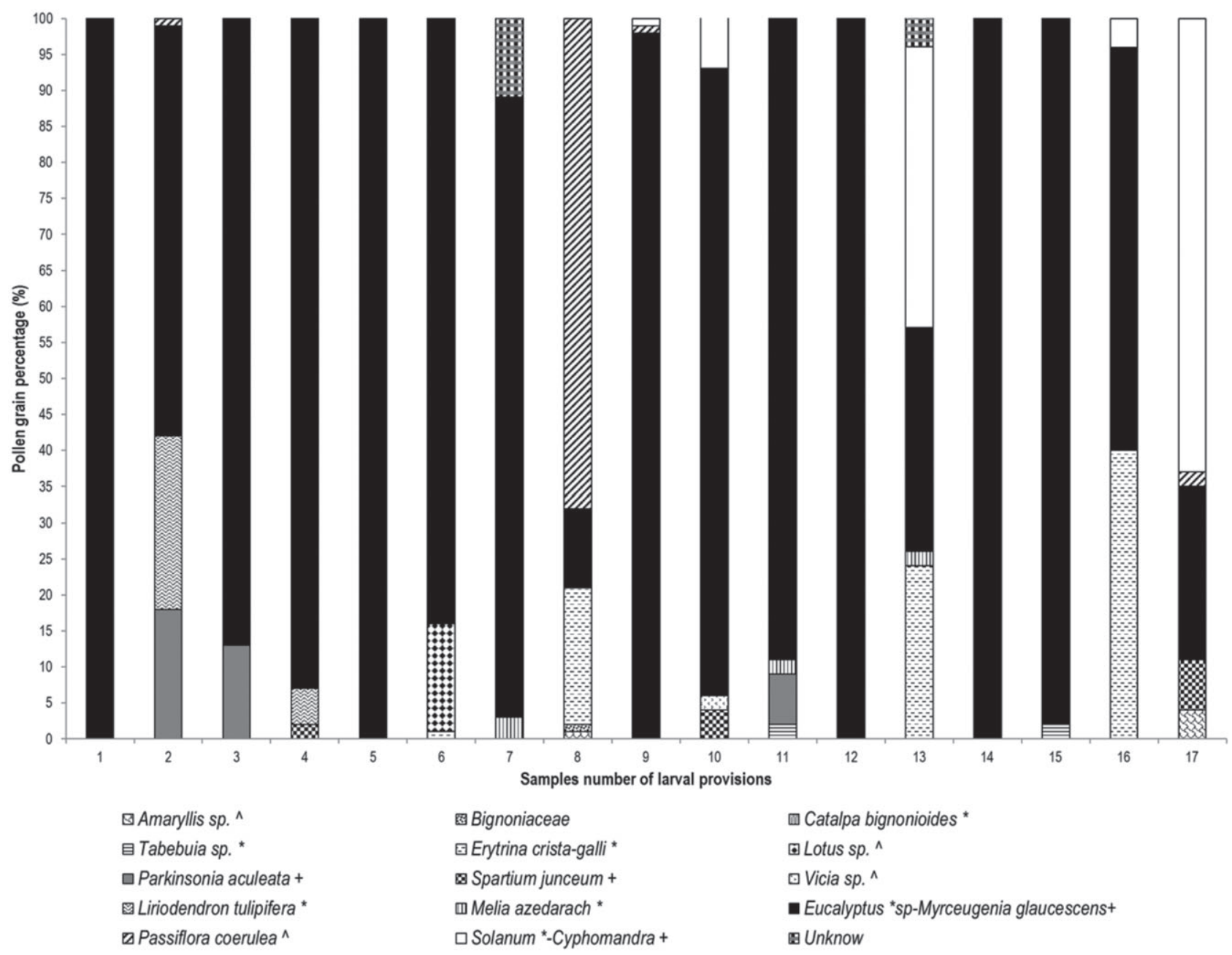

Figure 11 Percentages of more common pollen types present in samples from larval provisions of Xylocopa augusti collected during 2013. ^, herbs; *, trees; + , shrubs.

collect pollen in early October, continuing throughout the spring and decreasing markedly around the beginning of summer (late December). The most intense period of nesting activity coincides with the greatest blooming period of the surrounding flora, which occurs during October, November and December. Sakagami and Laroca (1971) noted the occurrence of a multivoltine lifecycle in $X$. augusti from Curitiba, Brazil, although our data indicate an univoltine lifecycle for this species in the study area. However, in two nests, we observed that females that emerged early in January started a new oviposition cycle. This suggests that $X$. augusti could have one additional generation in the summer and thus exhibit a bivoltine lifecycle. Vicidomini (1996) considered univoltism as an adaptation of the life cycle in regions where nesting in multiple periods of the year is not possible, probably as a result of the seasonality of pollen and nectar production by flowers used for the preparation of the larval food. This is consistent with the situation in the study area, in which winters are moderately cold, with mean temperatures dropping to 10 and $11^{\circ} \mathrm{C}$, and the presence sporadic frost spells (Fig. 1). During this period, floral resources are not available, and the female stops provisioning and overwinters. Females can make foraging trips during late winter (generally in late August or early September) and on warm days when the temperatures exceed $25^{\circ} \mathrm{C}$.

During the cell provisioning season, $X$. augusti females concentrated their pollen collection to the morning and decreased trips in the afternoon. By contrast, trips to collect nectar increased around noon; this might be related to the floral biology of P. caerulea, the main nectar source used by Xylocopa females. Amela García and Hoc (1997) regard X. augusti as the principal pollinator of Passiflora and suggest a possible adaptative relationship between them. In the present study, the frequency of nectar visits of $X$. augusti to Passiflora increased after $12.30 \mathrm{~h}$, with a peak of visits at $16.30 \mathrm{~h}$ coinciding with the main nectar offering recorded by Amela García and Hoc (1997).

\section{Plants foraged by $X$. augusti}

The pollen spectrum obtained from our samples shows that $X$. augusti uses a wide range of plant species. However, only a 
small group of tree and shrubs such as Eucalyptus-Myrceugenia glaucescens, Solanum sp.-Cyphomandra betacea and Erythrina crista-galli occurred commonly in the pollen provisions. Other plants were scarcely represented in the diet, and probably were only foraged for nectar. The plants visited tend to have inflorescences rather than solitary flowers, as commonly preferred by social bees (Augspurger, 1980). Pollen of Eucalyptus is commonly collected by both native and introduced bees (Tellería, 1998, 2000; Abrahamovich etal., 2001; Cilla et al., 2012). Pollen of Erythrina crista-galli was intensely collected by $X$. augusti. This native tree has been considered as a hummingbird-pollinated species (Faegri \& van der Pijl, 1971; Hemsley \& Ferguson, 1985); however, studies of populations showed that they are also visited by species of Xylocopa and other Apidae (Galetto et al., 2000; Abrahamovich et al., 2001). Passiflora caerulea is self-incompatible and X. augusti is as one of its principal pollinators, with a high visitation frequency and activity during all floral phases (Amela García \& Hoc, 1997). This also occurs with $P$. edulis, which is successfully pollinated by species of Xylocopa in Brazil (Aguiar-Menezes etal., 2002). In the present study, although the pollen of $P$. caerulea was the most frequent type occurring in the provision, it was always present at low percentages. Field observations demonstrate that, when the pollen of Passiflora is carried by the female on the dorsal surface of mesosoma, once the female is inside the nest, it is removed and ejected towards the nest entrance. This might explain the low proportion of this pollen in the larval food and could be interpreted as a 'contaminant' component.

In the present study, the diversity of pollen types recorded in larval provisions of $X$. augusti was higher than that obtained in a rural environment of the Pampean Region of Argentina (Tellería, 1999), with more than 18 types compared with 10 , respectively. Considering that both studies were conducted in similar environments (offering both cultivated and ruderal plants), the variation may be a result of the sample size, which was broader in the present study. However, in both studies, pollen of Solanum appears to be one of the most important elements of the larval diet. It is important to note that, despite the scarcity of Solanun species around the nests, it was one of the most important food sources in the larval diet. The ease of acceptance of trap-nests by $X$. augusti females, its abundance in the study region, and the skill in obtaining pollen from poricidal anthers such as those of Solanum all indicate the potential of this species to be an excellent managed pollinator in horticultural crops. Similarly, the plasticity of $X$. augusti to use other nectar and pollen sources, as indicated in the pollen spectrum, emphasizes its potential as a pollinator of plants in restoring areas.

\section{Acknowledgements}

We thank Stephen Baca and the anonymous reviewers for their comments and suggestions that improved the manuscript. Special thanks are extended to the staff of Unidad de Vivero Forestal of Facultad de Ciencias Agrarias y Forestales, Universidad Nacional de La Plata, for their help. ML, AHA, PJR and MCT are supported by Consejo Nacional de Investigaciones Científicas y Técnicas, Argentina (CONICET). The study was financed by PICT 2012/No 2112 (FONCyT).

\section{References}

Abrahamovich, A.H., Tellería, M.C. \& Díaz, N.B. (2001) Bombus species and their associated flora in Argentina. Bee World, 82, 76-87. Abrol, D.P. (2012) Pollination Biology, Biodiversity Conservation and Agricultural Production. Springer, The Netherlands, Germany, U.K.

Aguiar-Menezes, E.L., Menezes, E.B., Cassino, P.C.R. \& Soares, M.A. (2002) Passion fruit. Passion Fruit in Tropical Fruit, Pests and Pollinators (ed. by J. E. Peña, J. L. Sharp and M. Wisoki), pp. 361-390. CAB International, Orlando, Florida.

Alvarez, J.L., Lucia, M., Aquino, D.A., Ramello, P.J. \& Abrahamovich, A.H. (2015) Nesting biology and associated insect enemies of the exotic leaf cutter bee Megachile (Eutricharaea) concinna (Hymenoptera: Megachilidae) in Argentina. Journal of Apicultural Research, 54, 305-313.

Amela García, M.T. \& Hoc, P.S. (1997) Floral biology and reproductive system of Passiflora caerulea (Passifloraceae). Beitrage zur Biologie der Pflanzen, 70, 1-20.

Augspurger, C.K. (1980) Mass flowering of a tropical shrub (Hybanthus prunifolius): influence on pollinator attraction and movement. Evolution, 34, 475-488.

Bernardino, A. \& Gaglianone, M.C. (2008) Nest distribution and nesting habits of Xylocopa ordinaria Smith (Hymenoptera, Apidae) in a restinga area in the northern Rio de Janeiro State, Brazil. Revista Brasileira de Entomologia, 52, 434-440.

Buchmann, S.L. (1983) Buzz pollination in angiosperms. Handbook of Experimental Pollination Biology (ed. by C. E. Jones and R. J. Little), pp. 73-113. Van Nostrand Reinhold, New York, New York.

Buchmann, S.L. (2004) Aspects of Centridine biology (Centris spp.) importance for pollination, and use of Xylocopa spp. as greenhouse pollinator of tomatoes and other crops. Solitary Bees. Conservation, Rearing and Management for Pollination (ed. by B. M. Freitas and J. O. P. Pereira), pp. 203-211. Imprensa Universitária, Brazil.

Camillo, E. \& Garófalo, C.A. (1982) On the bionomics of Xylocopa frontalis (Olivier) and Xylocopa grisescens (Lepeletier) in Southern Brazil. I. Nest construction and biological cycle. Revista Brasileira de Biologia, 42, 571-582.

Camillo, E., Garófalo, C.A. \& Muccillo, G. (1986) On the bionomics of Xylocopa suspecta (Moure) in southern Brazil: nest construction and biological cycle (Hymenoptera, Anthophoridae). Revista Brasileira de Biologia, 46, 383-393.

Cicchino, A.C., Marasas, M. \& Paleologos, M.F. (2003) Características e importancia de la carabidofauna edáfica de un cultivo experimental de trigo y sus bordes con vegetación en el partido de La Plata, Pcia. De Buenos Aires. Revista de Ciencia y Tecnología, 8, 41-55.

Cilla, G., Caccavari, M., Bartoloni, N.J. \& Roig-Alsina, A. (2012) The foraging preferences of two species of Melissodes Latreille (Hymenoptera, Apidae, Eucerini) in farmed sunflower in Argentina. Grana, 51, 63-75.

Erdtman, G. (1960) The acetolysis method. A revised description. Svenk Botanik Tidkrift, 54, 561-564.

Faegri, K. \& van der Pijl, L. (1971) The Principles of Pollination Ecology. Pergamon, U.K.

Free, J.B. (1993) Insect Pollination of Crops, 2nd edn. Academic Press, U.K.

Freitas, B.M. \& Oliveira Filho, J.H. (2001) Criação racional de mamangavas para polinização em áreas agrícolas. Banco do Nordeste, Brazil.

Galetto, L., Bernardello, G., Isele, I., Vesprini, J.L., Speroni, G. \& Berduc, A. (2000) Reproductive biology of Erythrina cristagalli (Fabaceae). Annals of the Missouri Botanical Garden, 87, 127-145.

Garibaldi, L.A., Steffan-Dewenter, I., Winfree, R. et al. (2013) Wild pollinators enhance fruit set of crops regardless of honey bee abundance. Science, 339, 1608-1611. 
Gerling, D., Hurd, P.D. Jr. \& Hefetz, A. (1983) Comparative behavioral biology of two Middle East species of carpenter bees (Xylocopa Latreille) (Hymenoptera: Apoidea). Smithsonian Contributions to Zoology, 369, 1-33.

Gerling, D.W., Velthuis, H.D. \& Hefetz, A. (1989) Bionomics of the large carpenter bee of the genus Xylocopa. Annual Review of Entomology, 34, 163-190.

Goulson, D. (2003) Effects of introduced bees on native ecosystems. Annual Review of Ecology, Evolution, and Systematics, 34, $1-26$.

Hemsley, A.J. \& Ferguson, I.K. (1985) Pollen morphology of the genus Erythrina (Leguminosae: Papilionoideae) in relation to floral structure and pollinators. Annals of the Missouri Botanical Garden, 72, 570-590.

Hogendoorn, K., Steen, Z. \& Schwarz, M.P. (2000) Native Australian carpenter bees as a potential alternative to introducing bumblebees for tomato pollination in greenhouses. Journal of Apicultural Research, 39, 67-74.

Hongjamrassilp, W. \& Warrit, N. (2014) Nesting biology of an Oriental carpenter bee, Xylocopa (Biluna) nasalis Westwood, 1838, in Thailand (Hymenoptera, Apidae, Xylocopinae). Journal of Hymenoptera Research, 41, 75-94.

Kearns, C.A., Inouye, D.W. \& Waser, N. (1998) Endangered mutualisms: the conservation of plant-pollinator interactions. Annual Review of Ecology and Systematics, 29, 83-112.

Keasar, T. (2010) Large carpenter bees as agricultural pollinators. Psyche 2010, $1-7$

Lucia, M., Alvarez, L.J. \& Abrahamovich, A.H. (2014) Large carpenter bees in Argentina: systematics and notes on the biology of Xylocopa subgenus Neoxylocopa (Hymenoptera: Apidae). Zootaxa, 3754, 201-238.

Lucia, M., Gonzalez, V.H. \& Abrahamovich, A.H. (2015) Systematics and biology of Xylocopa subgenus Schonnherria (Hymenoptera, Apidae) in Argentina. ZooKeys, 543, 129-167.

Marchi, P. \& Melo, G.A.R. (2010) Biologia de nidificação de Xylocopa (Neoxylocopa) frontalis (Olivier) (Hymenoptera, Apidae, Xylocopini) em Morretes, Paraná. Oecologia Australis, 14, 210-231.

Mardan, M. (1995) Varied pollinators for sub-tropical Asian crops. Pollination of Cultivated Plants in the Tropics (ed. by D. W. Roubik), pp. 142-148. FAO (UN), Italy.

Michener, C.D. (1964) Evolution of the nests of bees. American Zoologist, 4, 227-239.

O'Toole, C. (1997) Diversity of native bees and agroecosystems. Hymenoptera and Biodiversity (ed. by J. La Salle and I. D. Gauld), pp. 169-196. CAB International, U.K.

Pitts-Singer, T.L. \& Cane, J.H. (2011) The alfalfa leafcutting bee, Megachile rotundata: the world's most intensively managed solitary bee. Annual Review of Entomology, 56, 221-237.

Plischuk, S., Martín-Hernández, R., Prieto, L., Lucia, M., Botías, C., Meana, A. etal. (2009) South American native bumblebees (Hymenoptera: Apidae) infected by Nosema ceranae (Microsporidia), an emerging pathogen of honey bees (Apis mellifera). Environmental Microbioly Report, 1, 131-135.
Raju, A.J.S. \& Rao, S.P. (2006) Nesting habits, floral resources and foraging ecology of large carpenter bees (Xylocopa latipes and Xylocopa pubescens) in India. Current Science, 90, 1210-1217.

Sadeh, A., Shmida, A. \& Keasar, T. (2007) The carpenter bee Xylocopa pubescens as an agricultural pollinator in greenhouses. Apidologie, $\mathbf{3 8}$, 508-517.

Sakagami, S.F. \& Laroca, S. (1971) Observations on the bionomics of some neotropical Xylocopine bees, with comparative and biofaunistic notes (Hymenoptera, Anthophoridae). Journal of the Faculty of Science Hokkaido University, Series IV, Zoology, 18, 57-127.

Schmid-Hempel, R., Eckhardt, M., Goulson, D. et al. (2014) The invasion of southern South America by imported bumblebees and associated parasites. Journal of Animal Ecology, 83, 823-837.

Sihag, R.C. (1993a) Behaviour and ecology of the sub-tropical carpenter bee, Xylocopa fenestrata F.6 crop hosts and pollination potential. Journal of Apicultural Research, 32, 94-101.

Sihag, R.C. (1993b) Behaviour and ecology of the sub-tropical carpenter bee, Xylocopa fenestrata F.7. Nesting preferences and response to nest translocation. Journal of Apicultural Research, 32, 102-108.

Sihag, R.C. (1993c) Behaviour and ecology of the sub-tropical carpenter bee, Xylocopa fenestrata F.8. Life cycle, seasonal mortality, parasitization and sex ratio patterns. Journal of Apicultural Research, 32, 109-114.

Tellería, M.C. (1998) Palynological analysis of food reserves found in a nest of Bombus atratus (Hym. Apidae). Grana, 37, 125-127.

Tellería, M.C. (1999) Polen recolectado por Xylocopa augusti (Hymenoptera, Apidae) en el noroeste de la provincia de Buenos Aires, Argentina. Darwiniana, 37, 3-4.

Tellería, M.C. (2000) Exploitation of pollen resources by Xylocopa splendidula in the Argentine pampas. Journal of Apicultural Research, 39, 55-60.

Thorp, R.W. (2003) Bumble bees (Hymenoptera: Apidae): commercial use and environmental concerns. For Non-native Crops, Whence Pollinators of the Future? Proceedings of Thomas Say Publications in Entomology (ed. by K. Strickler and J. H. Cane), pp. 21-40. Entomological Society of America, Lanham, Maryland.

Torchio, P.F. (2003) The development of Osmia lignaria Say (Hymenoptera: Megachilidae) as a managed pollinator of apple and almond crops: a case history. For Nonnative Crops, Whence Pollinators of the Future? Proceedings, Entomological Society of America (ed. by K. Strickler and J. H. Cane), pp. 67-84. Thomas Say Publications in Entomology, Lanham, Maryland

Velthuis, H.H.W. \& van Doorn, A. (2006) A century of advances in bumble bee domestication and the economic and environmental aspects of its commercialization for pollination. Apidologie, 37, $421-451$

Vicidomini, S. (1996) Biology of Xylocopa violacea (Hymenoptera): in nest ethology. Italian Journal of Zoology, 63, 237-242.

Wittmann, D. \& Scholz, E. (1989) Nectar dehydration by male carpenter bees as preparation for mating flights. Behavioral Ecology and Sociobiology, 25, 387-391.

Accepted 16 November 2016 